\title{
THE SHAREHOLDERS' DERIVATIVE-CLAIM EXCEPTION TO THE ATTORNEY-CLIENT PRIVILEGE
}

\author{
I \\ INTRODUCTION
}

Shareholders and corporate management participate in a relationship in which management is normally the representative of the shareholders, but is at times their adversary. ${ }^{1}$ As representative, management needs the means to protect the corporate interest. The attorney-client privilege traditionally has been recognized as an important means of protecting that interest. ${ }^{2}$ Shareholders want management to make full use of the privilege in defending their interests against attacks from those outside the corporation. A fullfledged attorney-client privilege proves to be a double-edged sword, however, when shareholders bring a derivative action.

When shareholders in a derivative suit seek to pierce the corporate attorney-client privilege, courts are presented with three alternatives:

\footnotetext{
Copyright $\odot 1985$ by Law and Contemporary Problems

1. In litigation, the relationship between shareholders and management depends upon the nature of the suit. Three types of actions can be brought: (1) direct actions by the corporation; (2) direct actions by the shareholder; and (3) derivative actions. The clearest example of management defending the shareholders' interests is a direct suit brought by the corporation based on a cause of action that accrues in favor of the corporation against an outsider. In contrast, the clearest example of shareholders and management as adversaries occurs when a shareholder (or class of shareholders) brings a direct action against the corporation to enforce a cause of action belonging to the shareholder as an individual for breach of the shareholder's membership contract. See H. HenN \& J. Alexander, Laws of Corporations $\$ 360$, at $1044-45$ (3d ed. 1983).

When a derivative action is brought, the relationship between shareholders and management is more complex. The corporation occupies a dual position in the litigation. Because the corporation has refused to sue in its own name, the shareholder is the nominal party plaintiff, while the corporation is the real party plaintiff. In addition, the corporation is the nominal party defendant. An adversary relationship between the shareholder-plaintiff and management exists in the derivative suit regardless of whether the wrong to the corporation was allegedly perpetrated by management or by persons outside the corporation. See id. $\S 358$, at 1035-37. The adversary relationship is clearest when management is the alleged wrongdoer; however, the adversary relationship also exists when persons outside the corporation are the alleged wrongdoers, since the derivative suit, in effect, alleges that management has wronged the shareholders by failing to assert the corporation's cause of action in a direct action by the corporation against the outsiders. See id. $\S 358$, at $1035 ; \S 360$, at 1044.

2. See infra notes 40-43,59-62, \& 64-68 and accompanying text. As this note argues, the corporate interest is served by devices which furnish incentives for communications from clients to counsel. The same rationale for the attorney-client privilege in the corporate context is stressed in an article published after the body of this note was written. See Saltzburg, Corporate Attorney-Client Privilege in Shareholder Litigation and Similar Cases: Garner Revisited, 12 HOFSTRA L. REv. 817 (1984).
} 
(1) granting the shareholders unrestricted access to confidential communications; (2) treating the shareholders as outsiders to the corporation for purposes of the privilege and allowing the privilege to be pierced only pursuant to the common law exceptions; or (3) recognizing a derivative-claim exception to the privilege whereby the shareholders can pierce the privilege in circumstances in which an outsider would not be allowed to do so. The danger of strike suits and other abuses of the derivative suit renders the first alternative-unrestricted access to confidential communicationsunworkable. This note will analyze the choice between the second and third alternatives: whether the shareholder should be treated as an outsider with respect to the privilege or should be granted preferred status in piercing it.

Several courts have recognized a derivative-claim exception and allowed shareholders to pierce the corporate attorney-client privilege. ${ }^{3}$ This exception was initially recognized by the Fifth Circuit in Garner $v$. Wolfinbarger. ${ }^{4}$ No other federal court of appeals has adopted the exception; however, district courts outside the Fifth Circuit have recognized it. ${ }^{5}$ No court has expressly rejected the derivative-claim exception.

The derivative-claim exception has intuitive appeal. A derivative suit is brought for the benefit of the corporation; the shareholders seek confidential communications to vindicate corporate interests. Moreover, the shareholders, not the managers, own the corporation, and, as owners, pay the corporation's attorney fees. In addition, allowing managers to invoke the privilege to keep confidential communications from shareholders seems inconsistent with the duty of loyalty that management owes to shareholders.

This note argues (1) that the derivative-claim exception substantially undermines the corporate attorney-client privilege; (2) that the underlying rationale for the exception, and the benefits arising from it, do not justify allowing shareholders to have special access to confidential communications between management and corporate counsel; (3) that the exception is rarely,

3. In re LTV Sec. Litig., 89 F.R.D. 595, 606-11 (N.D. Tex. 1981) (class action brought by shareholders; court recognized derivative-claim exception but refused to allow privilege to be pierced); Ohio-Sealy Mattress Mfg. Co. v. Kaplan, 90 F.R.D. 21, 31 -32 (N.D. Ill. 1980) (derivative suit and class action; court recognized derivative-claim exception but refused to allow privilege to be pierced); Panter v. Marshall Field \& Co., 80 F.R.D. 718, 722 (N.D. Ill. 1978) (shareholder class action; court recognized derivative-claim exception and allowed privilege to be pierced); Cohen v. Uniroyal, Inc., 80 F.R.D. 480 (E.D. Pa. 1978) (securities fraud class action by shareholders; court recognized derivative-claim exception and allowed privilege to be pierced); In $r$ Transocean Tender Offer Sec. Litig., 78 F.R.D. 692, $694-97$ (N.D. Ill. 1978) (derivative suit and shareholder class action; court recognized derivative-claim exception and allowed privilege to be pierced); Broad v. Rockwell Int'l Corp., [1976-1977 Transfer Binder] Fed. SEC. L. Rep. (CCH) If 95,894 (N.D. Tex. 1977) (debenture holders asserted securities law violation and breach of fiduciary duty against corporation; court recognized derivative-claim exception and allowed privilege to be pierced); George v. LeBlanc, 78 F.R.D. 281, 289-90 (N.D. Tex. 1977) (derivative suit; court applied derivative-claim exception and allowed privilege to be pierced); Valente v. Pepsico, Inc., 68 F.R.D. 361 (D. Del. 1975) (shareholder class action; derivative-claim exception recognized and court allowed privilege to be pierced); Bailey v. Meister Brau, Inc., 55 F.R.D. 211 (N.D. Ill. 1972) (shareholder in target corporation allowed to pierce privilege of acquiring corporation).

4. 430 F.2d 1093 (5th Cir. 1970), cert. denied, 401 U.S. 974 (1971).

5. See supra note 3 . 
if ever, needed since the attorney-client privilege does not protect underlying facts, or place shareholders in a worse position than if management had never sought legal advice; and (4) that recognition of the exception diverts attention from the common law exceptions to the privilege and diffuses efforts to make the common law exceptions more effective in preventing abuses of the attorney-client privilege by management. The note first traces the development of the exception. ${ }^{6}$ After examining the purposes of the attorney-client privilege, the note analyzes the corporate attorney-client privilege in derivative suits and argues that the reasons supporting recognition of a strong privilege when outsiders sue the corporation apply with even greater force when shareholders bring a derivative suit. ${ }^{7}$ The note then examines the rationales underlying the exception ${ }^{8}$ and the complexity of the test used by courts in determining when to apply the exception, ${ }^{9}$ concluding that an exception to the attorney-client privilege for shareholders in derivative suits should not be recognized.

II

\section{The Emergence and Development of the Derivative-Claim Exception to the Attorney-Client Privilege}

\section{A. The Emergence of the Derivative-Claim Exception}

The attorney-client privilege ${ }^{10}$ is the oldest ${ }^{11}$ and most respected ${ }^{12}$ common law evidentiary privilege. Corporations are entitled to invoke the

6. See infra notes 14-33 and accompanying text.

7. See infra notes 34-72 and accompanying text.

8. See infra notes 73-121 and accompanying text.

9. See infra notes $122-202$ and accompanying text.

10. Dean Wigmore has set forth the circumstances under which a communication falls within the protection of the attorney-client privilege: (1) legal advice of any kind is sought; (2) the advice is sought from a professional legal adviser in his capacity as such; (3) the communications relate to that purpose; (4) the communications are made in confidence; (5) the communications are made by the client; and (6) a waiver has not occurred. $8 \mathrm{~J}$. Wigmore, Evidence $\$ 2292$ (McNaughton rev. ed. $1961)$.

Most courts have adopted Wigmore's formulation of the attorney-client privilege. See, e.g., United States v. Goldfarb, 328 F.2d 280, 281 (6th Cir.), cert. denied, 377 U.S. 976 (1964); Radiant Burners, Inc. v. American Gas Ass'n, 320 F.2d 314, 319 (7th Cir.), cert. denied, 375 U.S. 929 (1963); see also S. Saltzburg \& K. Redden, Federal Rules of Evidence Manual 234-35 (3d ed. 1982); Note, The Attorney-Client Privilege and the Corporate Client: Where Do We Go After Upjohn?, 81 Mich. L. REv. 665, 666-67 (1981).

Saltzburg, supra note 2 , at $818-24$, argues that Wigmore too sweepingly criticized privileges, leading to unwarranted judicial constriction. Saltzburg concludes, as does this note, that the narrowing of the privilege in shareholder suits is misguided.

11. $8 \mathrm{~J}$. WIGmore, supra note 10, $\$ 2290$; see also Gergacz, Attorney-Client Privilege, 37 Bus. Law. 461,473 (1982) (suggesting that the privilege originated with the Romans); Radin, The Privilege of Confidential Communication Between Lawyer and Clienl, 16 Calif. L. Rev. 487, 488 (1928). See generally Hazard, An Historical Perspective on the Attomey-Client Privilege, 66 CALIf. L. Rev 1061, 1069-70 (1978).

Originally, the attorney-client privilege protected the oath and honor of the attorney. $8 \mathrm{~J}$. WIGMORE, supra note $10, \S 2290$. Under the "oath and honor" justification of the privilege, the privilege belonged to the attorney (who could waive it) and ended once the litigation had been completed. The oath and honor justification of the privilege was rejected in England during the eighteenth century and replaced by the theory that the privilege promoted justice by encouraging 
privilege against persons outside the corporation. ${ }^{13}$ Whether a corporation can invoke the attorney-client privilege against its shareholders has been the subject of few judicial decisions. ${ }^{14}$ Before 1968 , there was only one reported opinion on the subject, and the court, in upholding the privilege, attributed no special significance to the fact that the party seeking to pierce the privilege was a derivative-suit plaintiff. ${ }^{15}$

The derivative-claim exception is the product of a single case, Garner $v$. Wolfinbarger. ${ }^{16}$ Garner remains the leading decision and the key to understanding the exception. Courts that have recognized the derivativeclaim exception have applied Garmer without questioning its underlying rationale and have assumed that the only issue is whether, on the facts of the case, the shareholder is entitled to pierce the privilege under the standard established in Garner.

full disclosure between client and attorney. Id. For a discussion of the modern rationale for the privilege, see notes $42-43$ and accompanying text.

12. See S. Saltzburg \& K. Redden, supra note 10, at 247 ("most widely respected common law privilege").

13. Upjohn Co. v. United States, 449 U.S. 383, 390 (1981).

14. See supra note 3 .

15. In Graham v. Allis-Chalmers Mfg. Co., 41 Del. Ch. 78, 88-89, 188 A.2d 125, 132 (1963), the court refused to allow the corporation's attorney-client privilege to be pierced by the plaintiffshareholder who sought to obtain confidential communications made by the managers to the corporate attorneys. In other contexts, however, two courts indicated a willingness to give shareholders special access to confidential communications. In News Journal Corp. v. State ex rel. Gore, 136 Fla. 620, 624, 187 So. 271, 272 (1939), the court stated in dictum that a shareholder could gain access to confidential communications through the right of inspection if the shareholder could show that the value of his shares was affected by the confidential communications. For a discussion of the attorney-client privilege and the right of inspection, see infra notes 76-84 and accompanying text.

In Pattie Lea, Inc. v. District Court, 161 Colo. 493, 498, 423 P.2d 27, 30 (1967), the court held that the corporation could not assert a statutory accountant-client privilege against a shareholder bringing a derivative suit. This case provides little, if any, support by way of analogy to the issue of whether the shareholder should be allowed to pierce the corporate attorney-client privilege. A statutory accountant-client privilege is qualitatively different from the common law attorney-client privilege. The attorney-client privilege is recognized by all federal courts, while many federal courts have refused to recognize a privilege between accountants and their clients. See, e.g., United States v. Wainwright, 413 F.2d 796, 803 (10th Cir. 1969), cert. denied, 396 U.S. 1009 (1970). Moreover, statutory privileges are generally construed more strictly than common law evidentiary privileges. See Burnham, The Attomey-Client Privilege in the Corporate Arena, 24 Bus. Law. 901,912 n.27 (1969).

16. 430 F.2d 1093 (5th Cir. 1970), cert. denied, 401 U.S. 974 (1971). The derivative-claim exception to the attorney-client privilege, though not referred to as such, was first articulated in Garner. In Garner, shareholders brought a class action directly against the corporation and derivatively against its officers, alleging common law fraud and violations of state and federal securities laws. Id. at 1095 . The shareholders sought to compel the corporation's attorney to disclose advice he had given to the corporation prior to the filing of the derivative action. Id. at 1096 . The corporation objected on the grounds that the attorney-client privilege protected confidential communications between management and the corporation's attorney. The district court held that the privilege could not be asserted by the corporation against its shareholders.

On appeal, the Fifth Circuit vacated the district court's holding and held that when shareholders bring suit against the corporation alleging that the corporation had acted inimically to shareholder interests, the corporation's right to assert the privilege is subject to the right of the shareholder to show cause why the corporation should not be allowed to invoke the privilege. Id. For a discussion of the requirements for showing "cause" under Garner, see infra notes 17-20 and accompanying text. A discussion of the rationale underlying the derivative-claim exception is infra at notes 73-121 and accompanying text. 
To establish the derivative-claim exception to the attorney-client privilege, the shareholder must show "good cause" why the corporation should not be entitled to invoke the privilege. ${ }^{17}$ Garner set forth nine factors that may contribute to a finding of the presence or absence of good cause:

the number of shareholders and the percentage of stock they represent;

the bona fides of the shareholders;

the nature of the shareholders' claim and whether it is obviously colorable;

the apparent necessity or desirability of the shareholders having the information and the availability of it from other sources;

whether, if the shareholders' claim is of wrongful action by the corporation, it is of action criminal, or illegal but not criminal, or of doubtful legality;

whether the communication related to past or to prospective actions; whether the communication is of advice concerning the litigation itself;

the extent to which the communication is identified versus the extent to which the shareholders are blindly fishing;

the risk of revelation of trade secrets or other information in whose confidentiality the corporation has an interest for independent reasons. ${ }^{18}$

The court did not specify how much weight any of the factors should be given, nor did it elaborate on their meaning. It left open the possibility that other factors might later be discovered ${ }^{19}$ and noted that both in camera inspections and protective orders could be used to limit disclosure of the confidential communications. ${ }^{20}$

In support of the derivative-claim exception, Garner analogized the shareholders' attempt to pierce the privilege to the joint-client exception to the privilege, ${ }^{21}$ the crime-fraud exception to the privilege, ${ }^{22}$ and the shareholder's right of inspection. ${ }^{23}$ In proposing the derivative-claim exception, the court also relied on three aspects of the relationship between management and shareholders: (1) the mutuality of interest between shareholders and management in the use of confidential communications for the benefit of the corporation; (2) the proprietary interest which shareholders have in the corporate attorney's advice; and (3) the inconsistency of allowing management to invoke the privilege to keep confidential communications

17. Garner, 430 F.2d at 1103-04.

18. Id. at 1104 .

19. See id.

20. Id.

21. See infra notes 85-91 and accompanying text.

22. See infra notes $92-99$ and accompanying text.

23. See infra notes 76-84 and accompanying text. 
from shareholders in all cases with the fiduciary duty of loyalty that management owes to the shareholders. ${ }^{24}$ The derivative-claim exception assumes that disclosure of confidential communications to shareholders will not significantly discourage managers from seeking legal advice, encourage the corporate attorney to hedge or soften the legal advice provided, or undermine counsel's efforts to prompt corporate compliance with the law. ${ }^{25}$

\section{B. The Development of the Derivative-Claim Exception}

From its inception, the derivative-claim exception has provided minimal predictability in determining when confidential communications between management and corporate counsel will be protected. Initial optimism that the nine factors set forth in Garner would provide lower courts with guidance, and thereby foster greater certainty, was misplaced. Instead of evolving into a predictable test, the opposite has occurred. Issues which appeared to be resolved in Garner, ${ }^{26}$ such as which party bears the burden of proof, have turned out to be open questions ${ }^{27}$ for courts outside the Fifth Circuit, with some courts placing the burden on the plaintiff-shareholder, ${ }^{28}$ others placing it on the corporation, ${ }^{29}$ and one suggesting the burden shifts depending upon which factors are at issue. ${ }^{30}$ Similarly, fifteen years of application of the derivative-claim exception have not eliminated the substantial uncertainty surrounding (1) how the factors should be applied," (2) how much weight should be given to each factor, ${ }^{32}$ and (3) when the exception will be recognized. ${ }^{33}$ In combination, these unresolved issues introduce substantial uncertainty about when confidential communications between management and corporate counsel will be protected. This uncertainty, in turn, chills communications between management and corporate attorneys, making it less likely that corporate counsel will be able to prompt corporate compliance with the law.

The fifteen years since Garmer have been characterized by judicial reluctance to question the underlying rationale of the derivative-claim

24. See Garner, 430 F.2d at 1101-02. For a discussion of these rationales, see infra notes 100-21 and accompanying text.

25. See Garner, 430 F.2d at 1102. For a discussion of this point, see infra notes 34-72 and accompanying text.

26. Gamer placed the burden of proving "good cause" to pierce the privilege on the shareholder. $430 \mathrm{~F} .2 \mathrm{~d}$ at 1103-04 (the corporation can invoke the privilege "subject to the right of the stockholders to show cause why it should not be invoked in the particular instance").

27. See In re Transocean Tender Offer Sec. Litig., 78 F.R.D. 692, 695-96 (N.D. Ill. 1978) (noting contradictory precedents and choosing to leave the question open).

28. See, e.g., Quintel Co. v. Citibank, 567 F. Supp. 1357, 1363 (S.D.N.Y. 1983); Ohio-Sealy Mattress Mfg. Co. v. Kaplan, 90 F.R.D. 21,31 (N.D. Ill. 1980).

29. See Valente v. Pepsico, Inc., 68 F.R.D. 361, 367 (D. Del. 1975) ("the corporation is not entitled to claim the privilege as against its own shareholders, absent some special cause").

30. See, e.g., Panter v. Marshall Field \& Co., 80 F.R.D. 718, 723 (N.D. Ill. 1978) ("no argument has been made that the information contained in these documents is available to the plaintiffs from other sources"').

31. See infra notes $139-41$ and accompanying text.

32. See infra notes $142-45$ and accompanying text.

33. See infra notes $130-38$ and accompanying text. 
exception. Courts other than the Court of Appeals for the Fifth Circuit have adopted the exception without questioning whether (1) a mutuality of interest actually exists between management and the shareholders as to the use of confidential communications in derivative suits, (2) shareholders have a proprietary interest in the corporate counsel's advice to management, (3) allowing management to invoke the privilege is inconsistent with the fiduciary duty of loyalty that management owes the shareholders, (4) the exception will encourage corporate counsel to hedge or soften legal advice provided, or (5) the exception will undermine counsel's efforts to prompt corporate compliance with the law. Moreover, courts adopting the derivative-claim exception have failed to consider the counterproductive effect the exception has had on the development of common law limitations on the misuse of the privilege-the derivative-claim exception diverts attention from efforts to modify the joint-client and crime-fraud exceptions to the privilege.

\section{III}

\section{The Corporate Attorney-Chient Privilege in Derivative Suits}

The purpose of the attorney-client privilege is "to encourage full and frank communication between attorneys and clients and thereby promote broader public interest in the observance of law and administration of justice." 34 To fulfill its purpose, the attorney-client privilege must serve three functions: (1) encourage full and frank disclosure of information to the attorney; (2) protect the advice given by the attorney to the client; and (3) promote compliance with the law. ${ }^{35}$

The Federal Rules of Evidence do not prohibit federal courts from recognizing new exceptions to the attorney-client privilege; however, any exception to the privilege must be consistent with "the principles of the common law as they may be interpreted by the courts of the United States in light of reason and experience." 36 The derivative-claim exception is inconsistent with the purpose of the attorney-client privilege and the "principles of the common law" which undergird the privilege because the exception (1) discourages full and frank communication of information from management to the corporate attorney, ${ }^{37}$ (2) adversely affects the quality of advice corporate counsel provides management, ${ }^{38}$ and (3) hinders corporate counsel's efforts to ensure that management complies with the complex regulatory scheme confronting the corporation. ${ }^{39}$

34. Upjohn Co. v. United States, 449 U.S. 383, 389 (1981).

35. See id. at 390-92.

36. FED. R. Evid. 501.

37. See infra notes 40-58 and accompanying text.

38. See infra notes 59-63 and accompanying text.

39. See infra notes 64-72 and accompanying text. 
A. The Derivative-Claim Exception Discourages Full and Frank Disclosure of Information to the Corporate Attorney

In resolving any legal problem, the lawyer's first step is to learn all of the facts. ${ }^{40}$ This task is made difficult by the tendency of clients to omit facts that the client views as adverse or unimportant. ${ }^{4}$ Often the client's evaluation of the facts is incorrect; facts that the client views as adverse may turn out to be harmless, or even favorable, while facts that the client views as unimportant may turn out to be crucial.

Encouraging full and frank disclosure of facts to the attorney is one of the functions of the attorney-client privilege. ${ }^{42}$ The theory underlying this function of the privilege goes to the heart of the adversary system of justice: justice is promoted when each party is represented by an effective advocate; a lawyer can only be effective if he knows all of the facts; and a client will make a full and frank disclosure of facts to the attorney only under a guarantee of confidentiality. ${ }^{43}$

While the relationship between the scope of the privilege and the willingness of the client to disclose information to the attorney has not been empirically verified, ${ }^{44}$ the Supreme Court has assumed that a direct relationship exists between the privilege's scope and the client's willingness to make full and frank disclosure. ${ }^{45}$ The Court has not engaged in a context-bycontext balancing 46 of the costs of the privilege against the incremental increase in disclosure of information to the attorney. The broad, protective rule that the Court has adopted for determining the scope of the attorneyclient privilege reflects the great weight the common law has given to the privilege and suggests that the Court would not consider the scope of the

40. See Upjohn Co. v. United States, 449 U.S. 383, 390-91 (1981).

41. See C. McCormick, McCormick on Evidence $\$ 87$, at 205 (3d ed. 1984).

42. Upjohn Co. v. United States, 449 U.S. 383, 389 (1981).

43. See id.

44. The only empirical study of the relationship between the scope of the privilege and the willingness of the client to disclose information to the attorney produced inconclusive results. See Note, Functional Overlap Between the Lawyer and Other Professionals: Its Implications for the Privileged Communications Doctrine, 71 YALE L.J. 1226, 1262 (1968) (55 of 108 laymen would be less willing to provide information if the privilege were abolished, 37 would not be less willing, and 16 did not know); see also Sexton, $A$ Post-Upjohn Consideration of the Corporate Attorney-Client Privilege, 57 N.Y.U. L. REv. 443, 473 n.115 (1982).

45. See Sexton, supra note 44 , at $474 \mathrm{n} .116$ ("The intensity with which the Court holds this intuition [that a relationship exists between the scope of the privilege and the willingness of the client to disclose information to the attorney] cannot be doubted."). "Unless such evidence [showing that the flow of information to the attorney does not increase with the protection of the privilege] is available, however, the development of doctrine regarding the corporate privilege will be heavily influenced by the Court's belief that the privilege produces an increment in the information available to attorneys." Id. at 474.

46. In other areas of the law, the Court has engaged in a context-by-context balancing of the costs and benefits of extending a protective rule. For example, when the Court is considering whether to extend the exclusionary rule to a new context, it weighs the costs and benefits of the extension. The fact that the Court does not engage in a context-by-context weighing of the costs and benefits of the attorney-client privilege reflects the strength of the common law assumption that there is a direct relationship between the scope of the privilege and the client's willingness to disclose information to the attorney. 
privilege to be narrower in derivative suits than in actions brought by outsiders against the corporation. Moreover, even if the Court were to weigh the costs of the privilege against the incremental increase in disclosure of information to the attorney, the threat of strike suits and other abuses of the derivative suit suggests that even greater assurances of confidentiality are needed in derivative suits.

The derivative-claim exception to the attorney-client privilege discourages the communication of factual information to the attorney. Faced with the threat of disclosure, managers will be less willing to provide the attorney with all of the facts. The threat of disclosure to shareholders in a derivative suit is no less chilling on communications with the attorney than is the threat of disclosure to outsiders because in both cases managers face the possibility of personal liability and other undesirable consequences arising from litigation. ${ }^{47}$

Management may fear derivative suits more than actions brought by outsiders. Derivative liability has traditionally been recognized as encouraging many useless suits designed to enrich the plaintiff-shareholder ${ }^{48}$ or the plaintiff's attorney. ${ }^{49}$ While legislatures have attempted to prevent abuses of derivative suits, ${ }^{50}$ the danger of such abuse still exists. As a result, when managers foresee the possibility of a derivative action arising from a particular transaction, they may be inclined to disclose even less of the factual background to the corporate attorney than if the transaction were susceptible to attack only by those outside the corporation.

The substantial incentive to settle derivative suits, coupled with the threat of the use of the derivative-claim exception to pierce the privilege, point to a need for even greater protection of communications from managers to corporate counsel. The fee-setting mechanism in derivative litigation provides an incentive to bring actions primarily for the purpose of obtaining a settlement. ${ }^{51}$ The derivative-claim exception intensifies the already existing

47. The manager's eligibility for indemnification or entitlement to liability insurance may depend on how the suit is resolved. See H. Henn \& J. Alexander, supra note 1 , $\$ 380$, at $1125-28$ (discussing eligibility of managers to receive indemnification); id. $\$ 381$, at $1144-46$ (discussing entitlement to liability insurance).

48. See id. $\$ 358$, at 1039 .

49. See id. at n.22.

50. See generally Cox, Searching for the Corporation's Voice in Derivative Suit Litigation: A Critique of Zapata and the ALI Project, 1982 Duke L.J. 959, 959-60 (noting that the derivative suit has survived the adoption of security-for-expenses and indemnification statutes).

51. See, e.g., Conard, Winnowing Derivative Suits Through Attorneys Fees, Law \& Contemp. ProbS., Winter 1984, at 269,270 n.4 (noting that for the following reasons the corporate defendant has a strong incentive to settle a derivative suit even when there is a good chance that the plaintiff will not prevail on the merits: (1) the cost of settlement is usually less than the litigation costs of continuing the suit; (2) under indemnification laws of many states, the managers can be indemnified for litigation expenses when the suit is settled, but not when the managers are adjudged liable; and (3) the continuation of the suit exposes management to unfavorable publicity); Jones, An Empirical Examination of the Resolution of Shareholder Derivative and Class Action Lawsuits, 60 B.U.L. REv. 542, 54447 (1980) (study of 348 shareholder derivative and class action suits found that $70 \%$ settled, while plaintiff success rate in cases where a court entered a final judgment was only $2.3 \%$; author suggests that defendants settle unless there is a high probability of winning at trial). 
pro-plaintiff settlement bias. One commentator has suggested that the derivative-claim exception be used to "shock" management into settling. ${ }^{52}$ While management may be "shocked" into settlement once, it will take steps not to be placed in that position again. The easiest way to avoid an unfavorable settlement position would be to provide only a "sanitized" version of the facts to the corporate attorney. A "sanitized" version of the facts might be suitable for presentation at trial, but would not provide the full factual background that the attorney needs to provide legal advice.

The threat of derivative litigation does not provide management with sufficient incentive for full disclosure to corporate counsel. In United States $v$. Upjohn, ${ }^{53}$ the Court rejected the argument that the threat of civil or criminal liability provides managers with a sufficient incentive to make full disclosure to corporate counsel even when their communications with counsel are not protected. ${ }^{54}$ The Court noted that such an argument proves too much because it would apply with equal force to the individual, and the common law has "recognized the value of the privilege in further facilitating communications." 55 Similarly, the fact that disclosure would be for the "benefit of the corporation," or that other incentives may prompt disclosure, would also prove too much if it were argued that the threat of a derivative suit provided sufficient incentive for full disclosure to the attorney when those communications could later be presented in court under the derivative-claim exception.

Moreover, the derivative-claim exception is not needed in shareholder litigation since the attorney-client privilege does not protect facts from being discovered; the privilege only prevents discovery through the attorney. ${ }^{56}$ Shareholders in a derivative suit will not be prevented from discovering facts from the managers. The privilege protects only communications made to the attorney. The privilege, when applied to confidential communications between the managers and the corporate attorney, places the shareholder in no worse a position than if the communication had never been made. ${ }^{57}$ Considerations of convenience do not justify an exception to the attorneyclient privilege. ${ }^{58}$

B. The Derivative-Claim Exception Fails to Protect Adequately the Advice Given by the Attorney to the Client

In addition to facilitating the communication of facts by the client to the attorney, the attorney-client privilege exists to protect the giving of legal

52. See O'Neal \& Thompson, Vulnerability of Professional-Client Privilege in Shareholder Litigation, 31 Bus. LAW. 1775, 1775 (1976).

53. 449 U.S. 383 (1981).

54. Id. at 393 n.2.

55. Id.

56. See id. at 395 ("The privilege only protects disclosure of communications; it does not protect disclosure of the underlying facts by those who communicated with the attorney").

57. See id.

58. See id. at 396. 
advice to the client. ${ }^{59}$ The justification underlying this second function of the privilege is two-fold. First, extending the privilege to protect the advice given by the attorney is inextricably linked to the protection of the client's disclosure of facts to the attorney: protection of communications to the attorney would be rendered nugatory if the attorney's advice could be introduced at trial to show circumstantially the facts upon which the advice was based.60 Therefore, the reasons that support protecting disclosure of confidential communications from the client to the attorney ${ }^{61}$ also support the protection of communications from the attorney to the client.

The second justification is also based on the direct relationship between the scope of the privilege's protection and the quality of advice the attorney provides the client. In Upjohn, the Court emphasized that if the protection of the privilege was not available, "the depth and quality of the investigations [by corporate counsel] to ensure compliance with the law would suffer."62 Since the depth and quality of corporate counsel's investigations are directly related to the protection afforded by the privilege, the quality of advice provided to management would also be affected by the scope of the privilege's protection. The derivative-claim exception, with its substantial threat of disclosure, will prompt the corporate attorney to hedge his advice or shape it in anticipation that the advice may be discoverable in subsequent shareholder litigation. ${ }^{63}$ If the corporate attorney knows that his advice to management is protected and management wants to do something that is arguably illegal, the attorney serves the corporate interest by counselling that the proposed action should not be taken. But if the attorney knows that his advice will be played back at trial, the attorney may choose to waffle, since that best serves management's interests.

\section{The Derivative-Claim Exception Hinders Corporate Counsel's Efforts to Ensure Corporate Compliance with the Law}

In addition to encouraging management to make full and frank disclosure to corporate counsel and protecting counsel's advice to the client, the corporate attorney-client privilege promotes "the valuable efforts of corporate counsel to ensure their client's compliance with the law." 64 In Upjohn, the Court emphasized "the vast and complicated array of regulatory legislation confronting the modern corporation," 65 the difficulty in distinguishing economically justifiable business conduct from behavior

59. See id. at 390.

60. See C. McCormick, supra note 41, §89, at 212.

61. See supra notes $40-58$ and accompanying text.

62. 449 U.S. 383,393 n.2.

63. One corporate attorney, in describing how the derivative-claim exception affected his practice, wrote tongue (presumably) only half in cheek: "[T]he best rule is the rule of preventive medicine. Do not write very much. Keep all your notes on a pad that says at the top, 'Ladies and gentlemen of the jury.'" Ward, The Attorney-Client Privilege: A Litigator's Perspective, 6 DEL. J. CoRP. L. 447, 452 (1981).

64. Upjohn Co. v. United States, 449 U.S. 383, 392 (1981)

65. Id. 
proscribed by antitrust laws, ${ }^{66}$ and the corporation's great need for legal advice. The Court, however, rejected the argument that because of the corporation's great need for legal advice, management would seek legal advice even if substantial uncertainty existed as to whether the privilege was available. ${ }^{67}$ The Court emphasized that corporate counsel's efforts to make internal investigations to ensure compliance with the law would be impermissibly impaired if the protection of the privilege were not available. ${ }^{68}$

The derivative-claim exception undermines corporate counsel's efforts to ensure compliance with the law. The exception discourages management from making full and frank disclosure to counsel, ${ }^{69}$ thereby screening information from the corporate attorney that is needed to ensure such compliance. Similarly, the exception prompts counsel to soften or hedge advice to management in anticipation that the advice will later be discoverable. ${ }^{70}$ In addition, the threat of disclosure posed by the derivativeclaim exception discourages corporate counsel's efforts to make extensive investigations of corporate activities to ensure corporate compliance with the law. As a result, the derivative-claim exception, which purports ${ }^{71}$ to enhance the role the derivative suit plays in encouraging corporate compliance with the law, threatens to displace the primary means of ensuring such compliance: counsel's ongoing advice to management. ${ }^{72}$

\section{IV}

\section{Justifications for Carving Out a Derivative-Claim Exception}

When Congress enacted Federal Rule of Evidence 501, it chose not to freeze the law of evidentiary privileges, but rather to allow the federal courts to continue to develop the decisional law. ${ }^{73}$ Accordingly, federal courts have the authority to carve out exceptions to the attorney-client privilege as long as

66. See id.

67. See id. at 393 n.2.

68. See id.

69. See supra notes 40-58 and accompanying text. Similarly, Saltzburg, supra note 2, at 832, criticizes Gamer for failing to mention the incentive for communications which lies at the heart of the attorney-client privilege.

70. See supra notes 59-63 and accompanying text.

71. For a discussion of reasons why the derivative-claim exception is not needed by shareholders in a derivative suit, see supra notes 56-58 and accompanying text.

72. See Burnham, The Attorney-Client Privilege in the Corporate Arena, 24 Bus. L.Aw. 901, 914 (1969) ("[S]ecurities law [both federal and state] ... and antitrust laws of all kinds . . . are areas of corporate law where there would seem to be an immense social benefit deriving from free interchange between corporations and their attorneys about how one should comply with the law. Without this level of primary enforcement by lawyers, these areas of the law in the modern context would be virtually unmanageable."); Miller, The Challenges to the Attorney-Client Privilege, 49 VA. L. Rev. 262, 268 n.25 (1963) ("Far more violations of the antitrust laws are probably prevented by competent advice given by legal counsel to corporate and individual clients than by prosecutions by the Department of Justice or by the Federal Trade Commission.' ") (quoting from a letter written by the Chairman of the Administrative Law Section of the District of Columbia Bar Association); Shenefield, Compliance Programs as Viewed from the Antitrust Division, 48 AnTiTrust L.J. 73, 73 (1979) ("the private bar is the front line of antitrust enforcement").

73. See Upjohn Co. v. United States, 449 U.S. 383, 396 (1981). 
any exception is consistent with the "principles of the common law."74 In justifying the derivative-claim exception to the attorney-client privilege, Garner relied on the fiduciary relationship that exists between management and shareholders, and referred by analogy to the joint-client and crime-fraud exceptions as well as to the right of inspection. ${ }^{75}$ An examination of each of these bases, with the latter considered first, suggests that the exception is inconsistent with the "principles of the common law."

\section{A. Shareholders' Right of Inspection}

In establishing the "good cause" standard for piercing the attorney-client privilege, Garmer stated:

This approach is neither new nor world-shaking. At common law the stockholder has the right to see corporate books and records but it is not unlimited. His demand must be germane to his interest as stockholder, and the interests of the corporation and other shareholders may control to deny inspection. ${ }^{76}$

This analogy to the right of inspection is fundamentally misleading because it implies that the analysis for finding "good cause" to pierce the attorney-client privilege is substantially the same as that used in deciding whether a shareholder can exercise the right of inspection. In drawing the analogy, the court failed to recognize significant differences between these two mechanisms for gaining information.

First, the analogy ignores the difference between the types of materials generally available under the right of inspection and those which traditionally have been protected by the attorney-client privilege. The right of inspection usually involves corporate books, records, and lists of shareholders. ${ }^{77}$ None of these materials is created or preserved with the expectation of confidentiality that surrounds communications seeking or containing legal advice. ${ }^{78}$ Moreover, since corporate records are not immune from civil discovery (absent an independent privilege), ${ }^{79}$ the right of inspection merely accelerates a shareholder-plaintiff's access to unprivileged documents. A derivative-claim exception to the attorney-client privilege should not be created by reference to the right of inspection, which has as its object materials that are not privileged.

The analogy to the right of inspection also fails to take account of the fact that different policies underlie the right of inspection and the attorney-client privilege. ${ }^{80}$ The right of inspection is based primarily on the shareholders'

74. See id

75. See Garner v. Wolfinbarger, 430 F.2d 1093, $1100-04$ (5th Cir. 1970), cert. denied, 401 U.S. 974 (1971).

76. Id. at 1104 n.21.

77. See H. Henn \& J. Alexander, supra note $1, \S 199$, at 537-40.

78. See Note, The Attorney-Client Privilege-The Corporation in Shareholder Litigation, 50 S. CAL. L. REv. 303, 320-21 (1977).

79. See generally Note, Discovery Against Corporations Under the Federal Rules, 47 Iowa L. REv. 1006 (1962).

80. See Note, supra note 78 , at 321 . 
need for corporate information. ${ }^{81}$ The attorney-client privilege, in contrast, rests on the proposition that "the detriment of justice from the power to shut off inquiry to pertinent facts in court . . . will be out-weighed by the benefits to justice (not to the client) from a franker disclosure in the lawyer's office." 82 Any exception to the attorney-client privilege should take account of the policies that underlie the privilege, but the Garmer analogy to the right of inspection failed to recognize those policies.

Moreover, extending the right of inspection to privileged information would subordinate the interests served by the attorney-client privilege to the policies served by the right of inspection. Courts have traditionally refused to do this. ${ }^{83}$ With the exception of one district court decision, reversed on appeal, no reported opinion has ever used the right of inspection to allow shareholders access to privileged corporate documents. ${ }^{84}$ Thus, the Garmer analogy not only ignores the strong policy of encouraging frank attorneyclient communications, but, in so doing, also disregards the historical limits upon the shareholders' right of inspection.

\section{B. The Joint-Client Exception to the Attorney-Client Privilege}

The joint-client exception ${ }^{85}$ to the attorney-client privilege is well established. ${ }^{86}$ Wigmore formulated the exception in the following terms: "when the same attorney acts for two parties having a common interest, and each party communicates with him ... [,] the communications ... are not privileged in a controversy between the original parties, inasmuch as the common interest and employment forbade concealment by either from the other."87 McCormick explains the exception as follows:

In the first place the policy of encouraging disclosure by holding out the promise of protection seems inapposite, since as between themselves neither would know whether he would be more helped or handicapped, if in any dispute between them, both could invoke the shield of secrecy. And secondly, it is said that they had obviously no intention of keeping these secrets from each other, and hence as between themselves it was not intended to be confidential. ${ }^{88}$

Both rationales rest on the assumption that joint clients intend that nothing either says to their attorney will remain confidential from the other party.

The joint-client exception is consistent with, and can be explained in terms of, the attorney-client privilege. The primary purpose of the privilege is to encourage full and frank communication between client and counsel. ${ }^{89}$ In the typical joint-client case, two clients consult an attorney for their joint benefit.

81. See H. Henn \& J. Alexander, supra note 1, § 199, at 537.

82. C. MCCormick, supra note $41, \$ 87$.

83. See In re LTV Sec. Litig., 89 F.R.D. 595, 611 (N.D. Tex. 1981) ("evidentiary privileges are not subsidiary to shareholder's inspection rights").

84. See id. at 609-11.

85. Some commentators use the term "joint-attorney exception" instead of "joint-client exception."

86. See C. MсCовміск, supra note 41, §91, at 217.

87. See $8 \mathrm{~J}$. Wigmore, supra note 10, $\$ 2312$, at 603-04 (emphasis in original).

88. See C. McCormick, supra note $41, \S 91$, at 219.

89. See supra notes $40-43$ and accompanying text. 
Because both are present during the consultation, disclosures made cannot be intended to remain confidential as between the clients. ${ }^{90}$ Although disclosure to a third party normally waives the attorney-client privilege, the joint-client exception allows the confidential communications requirement to be waived as between the clients without requiring the clients to waive it with respect to the rest of the world.91 Being narrowly drawn, the joint-client exception does not undermine full and frank communication between client and attorney.

In contrast to the prototypical joint-client situation, there is no joint consultation involving the shareholders when corporate officials seek legal advice. Only managers or board members disclose information and receive advice. With respect to consultations in which they are not participants, shareholders are akin to third parties. Consequently, the derivative-claim exception, unlike the joint-client exception, undermines full and frank communications between corporate clients and their attorneys. Corporate officials are forced by the derivative-claim exception to choose between the full and frank disclosure necessary to obtain the best possible legal advice and disclosure which is less than full and frank in order to protect themselves from derivative-suit plaintiffs. Thus, the policy considerations which support the joint-client exception do not support a derivative-claim exception to the attorney-client privilege.

\section{The Crime-Fraud Exception to the Attorney-Client Privilege}

Although the attorney-client privilege has sometimes been viewed as a shield for criminal or fraudulent activity, ${ }^{92}$ the crime-fraud exception to the privilege is well established. ${ }^{93}$ This exception ensures that while attorneyclient communication after the client's commission of a crime or fraud are privileged, communications that facilitate a future crime or fraud are not privileged. ${ }^{94}$

The crime-fraud exception is consistent with the purposes of the attorneyclient privilege. Since the privilege protects attorney-client communications in order to promote the observance of law and the administration of justice, ${ }^{95}$ it should not be used to facilitate illegal actions. The crime-fraud exception thus allows the privilege to be pierced to prevent its abuse.

In Garner, the court used the crime-fraud exception to provide support by analogy for a broad derivative-claim exception to the attorney-client privilege. The court reasoned that "differences between prospective crime and

90. See, e.g., Hurlbert v. Hurlbert, 128 N.Y. 420, 28 N.E. 651 (1891). The joint-client exception to the privilege depends upon a finding that both parties actually sought legal advice and that the attorney in question actually did represent both clients. See, e.g., In re Colocotronis Tanker Sec. Litig., 449 F. Supp. 828, 830-32 (S.D.N.Y. 1978). See generally 8 J. Wigmore, supra note 10, § 2312.

91. See $8 \mathrm{~J}$. Wigmore, supra note 10, $\$ 2312$; of. In re International Sys. \& Controls Corp. Sec. Litig., 693 F.2d 1235, 1239 (5th Cir. 1981) (explaining the joint-client analogy as a fiction under which shareholders constructively hire corporate counsel).

92. See, e.g., Valente v. Pepsico, Inc., 68 F.R.D. 361, 369-70 n.16 (D. Del. 1975).

93. See C. MCCormick, supra note 41 , $\$ 95$.

94. See Proposed Fed. R. Evid. 503(d)(1).

95. See supra notes 64-68 and accompanying text. 
prospective action of questionable legality, or prospective fraud, are differences of degree, not of principle."96

The argument that the crime-fraud and derivative-claim exceptions are sufficiently similar to allow the former to support the latter by analogy ignores the more basic question whether the derivative-claim exception is needed to supplement the crime-fraud exception. One commentator, who notes that the existing crime-fraud exception is too narrow to include, for example, securities law violations that are merely negligently wrongful, argues that the crime-fraud exception could be expanded to cover "all communications made with the purpose of furthering an illegal, fraudulent, tortious, or otherwise actionable activity" vis-a-vis the shareholders. ${ }^{97}$ Such a modification of the crime-fraud exception would be consistent with the trend toward expanding the exception to include attorney-client communications used to facilitate torts as well as crimes and frauds. ${ }^{98}$ An expanded crime-fraud exception would be preferable to the derivative-claim exception because it would be clearly limited to prospective actions and would avoid introducing the hodgepodge of factors which makes the derivative-claim exception difficult to apply in a predictable fashion. ${ }^{99}$

\section{Fiduciary-Duty Exception to the Attorney-Client Privilege}

In Garner, the court emphasized that it was considering the attorney-client privilege in "a particularized context: where the client asserting the privilege is an entity which in the performance of its functions acts wholly or partly in the interests of others, and those others, or some of them, seek access to the subject matter of the communications." 100

[I]n assessing management assertions of injury to the corporation [from piercing the privilege,] it must be borne in mind that management does not manage for itself and that the beneficiaries of its action are the stockholders. Conceptualistic phrases describing the corporation as an entity separate from its stockholders are not useful tools of analysis. They serve only to obscure the fact that management has duties which run to the benefit ultimately of the stockholders. For example, it is difficult to rationally defend the assertion of the privilege if all, or substantially all, stockholders desire to inquire into the attorney's communications with corporate representatives who have only nominal ownership interests, or even none at all. There may be reasonable differences over . . . the extent to which corporate management is less of a fiduciary than the common law trustee. There may be many situations in which the corporate entity or its management, or both, have interests adverse to those of some or all stockholders. But when all is said and done management is not managing for itself. ${ }^{101}$

The court recognized that the shareholders and management had a mutual interest in management freely seeking legal advice when needed and putting

96. Garner v. Wolfinbarger, 430 F.2d 1093, 1103 (5th Cir. 1970), cert. denied, 401 U.S. 974 (1971).

97. See Note, supra note 78 , at 327,329 (emphasis in original).

98. See, e.g., Pfizer, Inc. v. Lord, 456 F.2d 545, 549 (8th Cir. 1973)

99. See infra notes $140-202$ and accompanying text.

100. Garner v. Wolfinbarger, 430 F.2d 1093, 1101 (5th Cir. 1970), cert. denied, 401 U.S. 974 (1971).

101. Id. (footnotes omitted). 
it to use when received. Nonetheless, it concluded that management judgment may not be shielded from shareholders by an "ironclad veil of secrecy." 102 The court accordingly rejected the argument that, in the long run, a fully protected privilege would benefit the shareholders more than would a derivative-claim exception. ${ }^{103}$

In emphasizing the uniqueness of the relationship between management and shareholders, Garner addressed three concerns: (1) the shareholders' proprietary interest in the attorney's advice; (2) a mutuality of interest between shareholders and management in using legal advice in the best interests of the corporation as a whole; and (3) the fiduciary relationship which exists between corporate officials and shareholders. ${ }^{104}$ In combination, these three concerns provide the most persuasive argument for the recognition of a derivative-claim exception. The argument is that the shareholders, rather than corporate officials, are paying for the attorney; therefore, the attorney's advice belongs to the shareholders. Those shareholders, in a derivative suit, seek to use the confidential legal communications for the benefit of the corporation. This argument concludes that the duty of loyalty owed by management to the shareholders supports an exception to the attorney-client privilege.

1. Shareholders' proprietary interest in the attomey's advice. In support of a derivative-claim exception to the attorney-client privilege, Garner emphasized that management might have only "nominal ownership interests, or even none at all" in the corporation. ${ }^{105}$ One implication from this observation is that legal advice given by a corporation's attorney belongs to the shareholderowners.

Other relationships, such as those between clients and accountants, are no less proprietary than the attorney-client relationship, but only independent statutory authority-and not the mere presence of a proprietary relationship-extends a privilege to communications made in the course of those relationships. ${ }^{106}$ Moreover, a proprietary notion of the attorney-client privilege could lead to absurd results, as in a civil action against the government in which the citizen-plaintiff would seek to pierce the privilege which exists between executive branch officials and their attorneys on the theory that the citizen has paid taxes and thus has a proprietary interest in any advice rendered. In reality, the attorney-client privilege is based not on protecting a proprietary interest, but rather on the theory that promoting confidential communications between client and attorney furthers the ends of justice. ${ }^{107}$ Again, any new exception to the attorney-client privilege should

102. Id.

103. See id. at 1102.

104. See infra notes $105-20$ and accompanying text.

105. Garner v. Wolfinbarger, 430 F.2d 1093. 1101 (5th Cir. 1970), cert. denied. 40I L.S. 97t

(1971)

106. See $8 \mathrm{~J}$. Wicmore, supra note $10, \$ 2286$.

107. See supra note $\mathbf{4 3}$ and accompanying text. 
take account of the purpose of the privilege and not simply refer to extrinsic notions such as protecting a proprietary interest.

2. Mutuality of interest in the use of advice for the benefit of the corporation. Garner recognized that corporate officials and shareholders have a "mutuality of interest" in management's "freely seeking advice when needed and putting it to use when received," but concluded that the "mutuality of interest" did not warrant management's erecting an "ironclad veil of secrecy."108 The "mutuality of interest" presumably refers to the common interest of the shareholders and management in doing what is best for the corporation. When derivative suit plaintiffs seek to pierce the attorney-client privilege, they argue that they are acting for the benefit of the corporation. ${ }^{109}$ This argument, by focusing on the short-term benefit to the corporation, undervalues long-term adverse effects caused by the vitiation of the corporate attorney-client privilege.

As amicus curiae in Garner, the American Bar Association (ABA) argued that the benefits flowing to the corporation from an exception to the privilege would be outweighed by the harm which would be done to both the corporate client and its attorney. ${ }^{110}$ The ABA emphasized that there was a direct relationship between the protection of the privilege and the quality of the advice provided by the attorney. The court rejected this argument and presumed that an exception to the privilege would not affect the quality of advice provided by the attorney. The court also presumed that a derivativeclaim exception would not affect the willingness of corporate officials fully to disclose potentially inculpatory information to their attorney, since they were under a duty to do so.111 By failing to recognize that the scope of the privilege might well affect both the willingness of a client to make a full disclosure and the ability of counsel to offer informed advice (legal obligations notwithstanding), the court ignored the long-term harm to the corporation and its shareholders that would result from a derivative-claim exception.

3. Fiduciary relationship between management and shareholders. In Garner, the court emphasized that "management has duties which run to the benefit ultimately of the stockholders."112 While recognizing that "corporate management is less of a fiduciary than the common law trustee," the court did not adequately distinguish between the two relationships and concluded simply that "when all is said and done management is not managing for itself." 113

108. Garner v. Wolfinbarger, 430 F.2d 1093, 1101 (5th Cir. 1970), cert. denied, 401 U.S. 974 (1971).

109. See id. at 1103 .

110. See id. at 1102 .

111. Id. Contra Upjohn Co. v. United States, 449 U.S. 383, 392 (1981).

112. Garner v. Wolfinbarger, 430 F.2d 1093, 1101 (5th Cir. 1970), cert. denied, 401 U.S. 974 (1971)

113. Id. 
The court's focus on fiduciary relationships ignores the differences between the management's relationship to the shareholder and the trustee's relationship to the beneficiary. A shareholder is not in as complete a state of dependence as the beneficiary of a trust because the shareholder is almost always in a better position to protect his interest. The shareholder-unlike the trust beneficiary, who is generally a donee without authority to manage the trust corpus-is an investor who can usually sell his stock. ${ }^{114}$ The fiduciary duty analogy thus assumes that the shareholder is more vulnerable than he generally is in fact.

Even if corporate officials are characterized as fiduciaries, an exception to the attorney-client privilege based upon the existence of a fiduciary duty is inconsistent with the purposes of the privilege. The attorney-client privilege rests on the proposition that the detriment to justice from denying access to relevant information is outweighed by the benefits to justice from a full and frank disclosure in the lawyer's office. ${ }^{115}$ Corporate officials-especially those who would like both to obey the law and to minimize legal liability-are less likely to discuss their legal problems with counsel if the communications can later be used against them in a derivative suit. ${ }^{116}$ Since an incompletely informed attorney is less able to encourage compliance with the law, an exception to the privilege based on extrinsic concerns, such as the existence of a fiduciary duty, is contrary to sound policy.

Moreover, basing the derivative-claim exception on the existence of a fiduciary duty poses a dangerous precedent by tapping judicial receptivity to the creation of a new exception wherever a fiduciary duty is thought to exist. In the years following Garner, courts have explicitly relied on its logic and created fiduciary-based exceptions to the attorney-client privilege: allowing shareholders in a target company to pierce the privilege of the acquiring company; ${ }^{117}$ allowing minority shareholders to pierce the privilege of another corporation which was the majority shareholder in the plaintiffs' corporation; ${ }^{118}$ allowing debenture holders to pierce the corporate privilege; ${ }^{119}$ allowing a defendant to pierce the privilege of the plaintiffshareholder; ${ }^{120}$ and allowing the Secretary of Labor to pierce the privilege held by the trustees of a union pension fund.121 These extensions of the derivative-claim exception to other fiduciary situations chill attorney-client

114. See Note, supra note 78, at 318-19; G. Bogert, Handbook of the Law of Trusts $\S 93$, at 337 (5th ed. 1973).

Shareholders in a close corporation may warrant special protection because no ready market exists for their shares. See H. Henn \& J. Alexander, supra note 1, §§ 257, 268, 276.

115. C. МсСовміск, supra note $41, \S 87$.

116. See supra notes 47-55 and accompanying text.

117. Bailey v. Meister Brau, Inc., 55 F.R.D. $211,213-14$ (N.D. Ill. 1972).

118. Valente v. Pepsico, Inc., 68 F.R.D. 361, 367-68 (D. Del. 1975).

119. Broad v. Rockwell Int'l Corp., [1976-1977 Transfer Binder] Fed. SEC. L. REP. (CCH) १ 95,894 (N.D. Tex. 1977).

120. George v. LeBlanc, 78 F.R.D. 281, 289-90 (N.D. Tex. 1977).

121. Donovan v. Fitzsimmons, 90 F.R.D. 583, 586 (N.D. Ill. 1981). 
communications both when the exception is thought to apply and even more perniciously when its applicability is uncertain.

\section{V \\ The Good-Cause Standard: An Invitation to Inconsistency}

Garner $v$. Wolfinbarger 122 established the principle that even when the attorney-client privilege would prevent the discovery of confidential communications between corporate officials and their attorneys in a nonderivative suit, shareholder-plaintiffs in a derivative action could show "good cause" why the privilege should not be invoked against them. Garmer set forth nine factors which indicate whether good cause has been established in a particular case. ${ }^{123}$ The inherent complexity and manipulability of a ninefactor test, however, make it difficult to predict whether good cause to pierce the privilege surrounding any particular attorney-client communication might later be found. Uncertainty in the application of the derivative-claim exception undermines the expectations of confidentiality which the attorneyclient privilege was designed to protect. ${ }^{124}$

A. The Need for a Test Which Produces Predictable Results: Upjohn Co. v. United States ${ }^{125}$

An important function of the attorney-client privilege in the corporate context is the facilitation of communication of all relevant information to the attorney so that he will be able to render legal advice to the corporate client. ${ }^{126}$ This function requires that attorney and client be able to predict with some degree of certainty whether particular discussions will be protected.127 In Upjohn, the Supreme Court rejected the "control group" test, which extended the attorney-client privilege only to those corporate officers who played a "substantial role" in deciding and directing a corporation's legal response. The Court noted that almost identical factual patterns produced opposite results when the "control group" test was applied and stated that an "uncertain privilege, or one which purports to be certain but results in widely varying applications by the courts, is little better than no privilege at all."

B. Unresolved Issues in Applying the Good-Cause Test

The "control group" test was rejected by the Supreme Court in Upjohn in part because it left attorney and client unable to predict with certainty

122. 430) F.2d 1093 (5th Cir. 1970), cert. denied, 401 U.S. 974 (1971).

113. Id.

124. Sef infra notes 125-202 and accompanying text.

125. 449 U.S. 383 (1981).

126 . In at 392. For a discussion of the purposes of the privilege, sec supra notes 34-72 and accompancing 1 exi.

127. i pyohn. 449 L.S. at 393.

Iax. Id. 
whether particular discussions would be privileged. In comparison, the Garmer derivative-claim exception is even more objectionable. The circumstances in which the exception applies are unclear. This difficulty is aggravated by the complexity and manipulability of the nine-factor good-cause test. ${ }^{129}$

The derivative-claim exception would clearly apply in a pure derivative action in which the shareholder-plaintiff brings suit only on behalf of the corporation and not also on behalf of himself or a class of shareholders of which he is a member. ${ }^{130}$ Beyond the pure derivative action, however, it is unclear when good cause may be shown to pierce the attorney-client privilege.

While the derivative-claim exception originated in Gamer, which involved class as well as derivative-claims, ${ }^{131}$ the district court in Ohio-Sealy Mattress Manufacturing Co. v. Kaplan ${ }^{132}$ refused to pierce the privilege in favor of shareholders who made both derivative and direct claims, because any information obtained in plaintiffs' role as derivative representatives could also be used to the corporation's detriment in the nonderivative causes of action. ${ }^{133}$ Thus, the court in Ohio-Sealy used one of the Garmer arguments in favor of the derivative-claim exception-that derivative suit plaintiffs should be allowed to pierce the privilege since they act for the benefit of the corporation $^{134}$ - to limit the exception to pure derivative suits, even though the facts in Garmer demonstrate that the exception was intended to apply to mixed derivative-class actions. ${ }^{135}$

After Ohio-Sealy, the Fifth Circuit reaffirmed its decision in Garner and applied the derivative-claim exception to an action that combined derivative and class claims. ${ }^{136}$ Faced with conflicting court opinions, attorneys and clients should assume that their communications will not be privileged from discovery by mixed derivative-class action plaintiffs. As the Supreme Court recognized in Upjohn, however, an uncertain privilege is little better than no privilege at all. ${ }^{137}$

While the court in Ohio-Sealy used a policy argument to narrow the derivative-claim exception, policy arguments have more often been used to expand the exception. For example, some courts have focused on the fiduciary relationship discussion in Garner and used the good-cause test to pierce the attorney-client privilege in contexts other than the derivative

129. See infra notes 139.45 and accompanying text.

130. See Kirby, New Life for the Corporate Attorney-Client Privilege, 69 A.B.A.J. 74, 176 (1983).

131. Garner v. Wolfinbarger, 430 F.2d 1093 (5th Cir. 1970), cert. denied, 401 U.S. 974 (1971).

132. 90 F.R.D. 21, 32 (N.D. Ill. 1980).

133. Id.; see also Weil v. Investment/Indicators Research \& Mgt., 647 F.2d 18, 23 (9th Cir. 1981). Compare Kirby, supra note 130, at 176 (Weil effectively limited Garmer to derivative actions) a'ith Lewis, The Availability of the Attorney-Client and Work-Product Privileges in Shareholder Litigation. 32 CLEV. ST. L. REV. 189, 204 (1984) (since Weil involved a direct claim of dubious merit by a single shareholder, the decision cannot be construed to be dispositive in all nonderivative suits).

134. See supra notes 108-09 and accompanying text.

135. Garner, 430 F.2d at 1095. 1982).

136. In re International Sys. \& Controls Corp. Sec. Litig., 693 F.2d 1235, 1239 n.3 (5th Cir.

137. Upjohn Co. v. United States, 449 U.S. 383, 393 (1981). 
suit. ${ }^{138}$ Such ex post facto expansions of the derivative-claim exception are especially objectionable because they violate expectations regarding which attorney-client communications are privileged.

Another reason why corporate attorneys and their clients cannot reliably predict whether their communications will be privileged from discovery by shareholder-plaintiffs is that the inherent complexity of the good-cause test makes it difficult to apply and easy to manipulate. To determine whether good cause to pierce the attorney-client privilege has been established in a particular shareholder action, Garner proposed a nine-factor test, the elements of which were not weighted. ${ }^{139}$

Although the court indicated that its list of nine factors was not exhaustive, ${ }^{140}$ subsequent decisions have treated the nine factors as the conclusive test for determining when the derivative-claim exception to the privilege should be recognized. ${ }^{141}$ While the as-yet-unused option to consider additional factors adds another element of uncertainty to the privilege, the nine already enunciated factors have proved impossible to apply in any predictable fashion.

Fifteen years after Garner, the courts have not reached a consensus on how much weight should be attributed to each of the nine elements of good cause. For example, one court has given determinative weight to whether the communication concerned past or prospective conduct, ${ }^{142}$ while another court did not consider that factor to be of great significance. ${ }^{143}$ Similarly, some courts have stated that the determinative factor is the plaintiff's need for the sought-after information, ${ }^{144}$ while other courts have not considered that factor to be of special importance. ${ }^{145}$ The varying weights given each factor suggest that the good-cause test provides little guidance to the courts or, worse, that the test is subject to manipulation by result-oriented courts that fix upon the factor which best supports the desired outcome. Moreover, the unpredictable weights given each element offer no guidance to attorney and client in assessing whether a particular conversation will be privileged.

\section{The Elements of Good Cause}

Not only is the nine-factor good-cause test too complex to apply in a principled and consistent fashion, ${ }^{146}$ but the individual factors are ill-defined and attempt to accomplish too many diverse objectives, most of which are extrinsic to the purposes of the attorney-client privilege. The derivative-claim

138. See supra notes 116-20 and accompanying text.

139. See Gamer, 430 F.2d at 1104; see also In re LTV Sec. Litig., 89 F.R.D. 595, 606 (N.D. Tex. 1981 ) (noting that Garner "did not direct how these [nine] factors should be evaluated.").

140. See Garner, 430 F.2d at 1104 .

141. See, e.g., George v. LeBlanc, 78 F.R.D. 281, 290 (N.D. Tex. 1977) (describing the nine factors as the "Wolfinbarger test").

142. Ohio-Sealy Mattress Mfg. Co. v. Kaplan, 90 F.R.D. 21, 31 (N.D. Ill. 1980).

143. In re Transocean Tender Offer Sec. Litig., 78 F.R.D. 692, 697 (N.D. Ill. 1978).

144. See, e.g., In re LTV Sec. Litig., 89 F.R.D. 595, 608 (N.D. Tex. 1981).

145. See, e.g., Ohio-Sealy Mattress Mfg. Co. v. Kaplan, 90 F.R.D. 21, $31-32$ (N.D. Ill. 1980).

146. See supra notes $142-45$ and accompanying text. 
exception undermines the privilege unnecessarily, because most of the goals that the complex good-cause test seeks to accommodate are already provided for by other exceptions to the privilege or substantive corporate law.

The first element in the Gamer good-cause test is the number of plaintiffshareholders and the percentage of stock which they represent. ${ }^{147}$ The court gave no indication of how many plaintiff-shareholders or what percentage of stock is necessary for this factor to weigh in favor of piercing the privilege, and no consensus has emerged on this point. Not surprisingly, courts have pointed to the joinder of only tiny minorities of shareholders as plaintiffs when upholding the privilege. ${ }^{148}$ Similarly, it is not surprising that courts have noted the joinder of overwhelming majorities of shareholders as plaintiffs to justify piercing the privilege. ${ }^{149}$ One court even suggested that substantial unanimity among shareholders would be decisive, thus collapsing the good-cause test into a single-factor test. ${ }^{150}$ That court also hinted that good cause could be found even though the class inquiring into the privileged communications was not comprised of a majority of the shareholders. ${ }^{151}$ Other courts have avoided the issue, simply noting the joinder of an unspecified but "substantial number" of shareholders as plaintiffs in support of decisions to pierce the privilege. ${ }^{152}$

As with the other eight elements of the good-cause test, Garner did not explain why the number of shareholders is relevant to the inquiry into the existence of good cause. ${ }^{153}$ Presumably, this indicator of good cause reflects the court's view that corporate management owes fiduciary duties to both suing and nonsuing shareholders. ${ }^{154}$ Since the corporation is "vulnerable to suit by shareholders whose interests or intentions may be inconsistent with those of other shareholders," 155 considering the number of plaintiffshareholders when deciding whether to pierce the privilege may deter strike suits or other suits inconsistent with the larger corporate interest. ${ }^{156}$ The deterrence of strike suits or of other suits inconsistent with the corporate interest, however, is a purpose extrinsic to the attorney-client privilege. Not only is the number of plaintiffs wholly unrelated to the functions of the privilege, but this element of the good-cause test undermines predictability

147. Garner v. Wolfinbarger, 430 F.2d 1093, 1104 (5th Cir. 1970), cert. denied, 401 U.S. 974 (1971). Saltzburg, supra note 2 , at 832 , asks why the number of shareholders or the percentage of stock should matter at all.

148. See e.g., Ohio-Sealy Mattress Mfg. Co. v. Kaplan, 90 F.R.D. 21, 31 -32 (N.D. Ill. 1980); see also Valente v. Pepsico, Inc., 68 F.R.D. 361, 370 (D. Del. 1975) (no good cause would exist where "the interests of the great majority of the beneficiaries would be better served by the privilege").

149. See, e.g., Panter v. Marshall Field \& Co., 80 F.R.D. 718,723 (N.D. Ill. 1978).

150. Cohen v. Uniroyal, Inc., 80 F.R.D. 480, 484 n.4 (E.D. Pa. 1978). The court erred in ascribing this position to Garmer. See id.

151. Id. at 484 n.4.

152. See, e.g., In re Transocean Tender Offer Litig., 78 F.R.D. 692, 696 (N.D. Ill. 1978); Broad v. Rockwell Int'l Corp., [1976-1977 Transfer Binder] Fed. SEc. L. Rep. (CCH) ๆ 95,894, at 91,304 (N.D. Tex. 1977).

153. See Garner, 430 F.2d at 1104.

154. See id. at 1101; accord In re LTV Sec. Litig., 89 F.R.D. 595, 606-07 (N.D. Tex. 1981 ).

155. Garmer, 430 F.2d at 1101 n.17.

156. See In re LTV Sec. Litig., 89 F.R.D. 595, 606-07 (N.D. Tex. 1981). 
because an attorney and client cannot foresee the number of putative plaintiffs at the time legal advice is sought or given. ${ }^{157}$

The second factor in the Garner good-cause analysis is the bona fides, or good faith, of the plaintiff-shareholders. ${ }^{158}$ Although sometimes mentioned by courts in support of decisions to pierce the privilege, ${ }^{159}$ this factor has never been determinative. On the other hand, the absence of good faith would indicate a strike suit and would likely be an important factor in a decision not to pierce the privilege. ${ }^{160}$ Since bad faith is more important in deciding to uphold the privilege than is good faith in deciding to pierce it, this element of the good-cause test would seem to support a stronger privilege. Because good faith is but one element in an unweighted balancing test, however, courts can use the plaintiffs' bona fides to offset another element of the test less favorable to their cause. Moreover, the second element of the good-cause test, like the first, accomplishes its deterrent function in a way that does not take account of the purposes of the attorney-client privilege and tends to undermine predictability because it is impossible to foresee the good faith of potential plaintiffs at the time legal advice is sought.

The third factor to consider under the Garner good-cause analysis is the nature of the shareholders' claim and whether it is obviously colorable. ${ }^{161}$ This factor, like the previous two, seems to reflect a concern for preventing strike suits. ${ }^{162}$ While the presence of a colorable claim has been mentioned in several decisions finding good cause to pierce the privilege, it has always been buried in a list of supporting factors and has never seemed decisive. ${ }^{163}$ Furthermore, this factor has never been cited in support of a decision to deny discovery, probably because the usual remedy for failure to state a colorable claim is a motion to dismiss. ${ }^{164}$ Although it has proved to be of little independent significance, the colorability element undermines the attorneyclient privilege in the same manner as does the good faith factor: by potentially offsetting another element of the good-cause test less favorable to the plaintiff, and by being incapable of prediction at the time legal advice is sought.

While screening out strike suits may be a worthwhile objective, the first three elements of the good-cause test do so at too great a cost to a viable

157. See Note, supra note 78 , at 322 .

158. Garner, 430 F.2d at 1104 . Saltzburg, supra note 2 , at 832 , comments that it is "difficult to understand how [bona fides] is to be determined."

159. See, e.g., Donovan v. Fitzsimmons, 90 F.R.D. 583, 587 (N.D. Ill. 1981); Cohen v. Uniroyal, Inc., 80 F.R.D. 480, 484 (E.D. Pa. 1978).

160. See In re International Sys. \& Controls Corp. Sec. Litig., 91 F.R.D. 552, 558 (S.D. Tex. 1981), vacated on other grounds, 693 F.2d 1235 (5th Cir. 1982); Valente v. Pepsico, Inc., 68 F.R.D. 361, 370 (D. Del. 1975).

161. Garner, 430 F.2d at 1104 . Saltzburg, supra note 2 , at 833 , questions whether a court can evaluate degrees of colorability.

162. See In re International Sys. \& Controls Corp. Sec. Litig., 91 F.R.D. 552, 558 (S.D. Tex. 1981), vacated on other grounds, 693 F.2d 1235 (5th Cir. 1982).

163. See, e.g., Donovan v. Fitzsimmons, 90 F.R.D. 583, 587 (N.D. Ill. 1981); In re Transocean Tender Offer Litig., 78 F.R.D. 692, 696 (N.D. Ill. 1978).

164. See Fed. R. Civ. P. 12(b)(6). 
attorney-client privilege. Problems such as strike suits can be governed and remedied by substantive corporate law. Those elements of the good-cause test aimed at deterring strike suits-the number of shareholder-plaintiffs, their bona fides, and the colorability of their claims-may all be considered by a corporate board, a special litigation committee, or a court (after a demand for action on the corporation has been made or excused). ${ }^{165}$ Likewise, statutes already exist to deter strike suits ${ }^{166}$ and could be amended if inadequate. There is thus no need to weaken the attorney-client privilege to deter strike suits.

The fourth element of the good-cause test is the apparent necessity or desirability of shareholders having the privileged information and the availability of the information from other sources. ${ }^{167}$ The absence of alternative sources of information has been cited in support of piercing the attorney-client privilege, ${ }^{168}$ and one court has suggested that the existence of alternative sources of information would be a decisive factor in refusing to pierce the privilege. ${ }^{169}$ When the desired information is available from other sources, the plaintiff who is denied privileged information is no worse off than if the corporation had never consulted counsel. Merely easing the burden of discovery for the plaintiff does not so benefit the fair and efficient processing of litigation as to outweigh the corporation's need to consult with its attorney in confidence. ${ }^{170}$ While an argument can be made that a plaintiff who alleges fraud and who consequently must prove scienter demonstrates a substantial need for privileged information, ${ }^{171}$ the preexisting common law crime-fraud exception allows a plaintiff to pierce the privilege only when it is used to further illegal activity. ${ }^{172}$ Since the attorney-client privilege rests on the proposition that "the detriment to justice from the power to shut off inquiry into pertinent factors in court ... will be outweighed by the benefits to justice . . . from a franker disclosure in the lawyer's office,"'173 the long-term interests of justice mandate that absent an exception such as that for

165. See generally Zapata Corp. v. Maldonado, 430 A.2d 779, 784 (Del. 1981) (board's decision to dismiss derivative suit as detrimental to the corporation's interests will be respected unless decision found not to be made independently, in good faith, and with reasonable basis).

166. See, e.g., Fed. R. Civ. P. 23.1; N.Y. Bus. Corp. Law §626 (McKinney 1963); Model Business Corp. ACr $\S 49$ (1953).

167. Gamer, 430 F.2d at 1104 . Saltzburg, supra note 2, at 833 , suggests that this factor begs the question.

168. See, e.g., Panter v. Marshall Field \& Co., 80 F.R.D. 718, (N.D. Ill. 1978); Cohen v. Uniroyal, Inc., 80 F.R.D. 480,484 (E.D. Pa. 1978); In re Transocean Tender Offer Litig., 78 F.R.D. 692,696 (N.D. Ill. 1978); Bailey v. Meister Brau, Inc., 55 F.R.D. 211,214 (N.D. Ill. 1972).

169. In re LTV Sec. Litig., 89 F.R.D. 595, 608 (N.D. Tex. 1981).

170. Id. at 609-10; see also Upjohn Co. v. United States, 449 U.S. 383, 396 (1981) ("considerations of convenience do not overcome the policies served by the attorney-client privilege").

171. See In re International Sys. \& Controls Corp. Sec. Litig., 91 F.R.D. 552, 559 (S.D. Tex. 1981), vacated on other grounds, 693 F.2d 1235 (5th Cir. 1982); Cohen v. Uniroyal, Inc., 80 F.R.D. 480, 484 (E.D. Pa. 1978); Lewis, supra note 133, at 209.

172. See supra notes $92-99$ and accompanying text.

173. C. MCCormick, supra note $41, \S 87$. 
prospective crimes and frauds, a plaintiff should not be allowed to pierce the privilege even on a showing of substantial need.

The apparent-necessity-or-desirability standard enunciated in Garmer has not traditionally been considered as a justification for piercing the attorneyclient privilege; rather, it is borrowed from the work-product exception. ${ }^{174}$ The Federal Rules of Civil Procedure provide that work product may, in general, be discovered upon a showing of substantial need and undue hardship. ${ }^{175}$ The Rules also provide, however: "In ordering discovery of such materials when the required showing has been made, the court shall protect against disclosure of the mental impressions, conclusions, opinions, or legal theories of an attorney or other representative of a party concerning the litigation." 176 In other words, only factual work product may be discovered upon a showing of substantial need and undue hardship. ${ }^{177}$ Since the required showing applies only to factual work product, and since underlying facts are not protected by the attorney-client privilege, ${ }^{178}$ Garmer's use of a borrowed work-product standard is inappropriate to the decision whether to pierce the attorney-client privilege.

A fifth element of the Garner good-cause analysis is the extent to which the desired communication is identified versus the extent to which the shareholders are blindly "fishing." 179 While often cited-though without special weight-among the list of factors supporting a decision to pierce the privilege, ${ }^{180}$ this factor has not been used in a reported case to support a finding of lack of good cause. Indeed, the very possibility that the identifiedcommunication/blindly-fishing factor might ever be used to bar discovery of privileged information has been vitiated by repeated holdings that this factor imposes no higher standard of relevance than that required by the Federal Rules of Civil Procedure. ${ }^{181}$ Since Rule 26(b)(1) allows the discovery of any information that is either admissible or reasonably calculated to lead to the discovery of admissible evidence, ${ }^{182}$ and since the good-cause test defines a "fishing expedition" in terms of Rule 26 irrelevance, this element of the Garner analysis can weigh against the discovery of privileged information only if that information would not be discoverable absent any privilege!

174. See Fed. R. Civ. P. 26(b)(3).

175. Id.

176. Id.

177. See Upjohn, 449 U.S. at 400 ("The Rule permits disclosure of documents and tangible things.").

178. Id. at 395.

179. Garner, 430 F.2d at 1104 . Saltzburg, supra note 2 , at 834 , doubts the clarity of a rule that fishing expeditions be avoided.

180. See, e.g., Broad v. Rockwell Int'l Corp., [1976-1977 Transfer Binder] FED. SEc. L. REP. (CCH) I 95,894 (N.D. Tex. 1977); Bailey v. Meister Brau, Inc., 55 F.R.D. 211 , 214 (N.D. Ill. 1972).

181. See Panter v. Marshall Field \& Co., 80 F.R.D. 718, 723 (N.D. Ill. 1978); Cohen v. Uniroyal, Inc., 80 F.R.D. 480, 484 (E.D. Pa. 1978); In re Transocean Tender Offer Litig., 78 F.R.D. 692, 697 (N.D. Tex. 1978); Broad v. Rockwell Int'l Corp., [1976-1977 Transfer Binder] Fed. SEC. L. ReP. (CCH) I 95,894 (N.D. Tex. 1977).

182. FED. R. Crv. P. 26(b)(1). 
The risk that trade secrets will be divulged is a sixth factor of the goodcause analysis. ${ }^{183}$ Although the absence of any trade secrets is frequently cited among a list of factors supporting a decision to pierce the privilege, ${ }^{184}$ this factor, like the identified-communication/blindly-fishing factor, has not been used to support a finding of lack of good cause and is unnecessary in any respect. While apparently designed to protect trade secrets from discovery, this factor provides no independent protection; whether or not the attorneyclient privilege is pierced, trade secrets are protected on independent grounds under the Federal Rules of Civil Procedure. ${ }^{185}$ Although this factor does not provide additional protection for trade secrets, it undermines the attorney-client privilege; the fact that the sought-after materials do not contain trade secrets is used to pierce a privilege, but the purpose of the privilege is wholly unrelated to the protection of trade secrets.

A seventh factor under the Garner analysis is whether the conduct complained of is criminal, illegal but not criminal, or of doubtful legality. ${ }^{186}$ This factor serves a useful purpose only to the extent that it would support piercing the attorney-client privilege in cases in which the traditional crimefraud exception would not do so. ${ }^{187}$ At first glance this Garner factor seems broader than the traditional crime-fraud exception because, unlike the traditional exception, it is not limited to communications made during or before the commission of a crime or fraud that assists in its commission. ${ }^{188}$ The good-cause analysis, however, has sometimes been interpreted to bar the disclosure of post-event legal communications, ${ }^{189}$ and there has been a trend toward expanding the crime-fraud exception to include attorney-client communications that facilitate other torts as well as crimes or frauds. 190 Thus, the crime-fraud exception and this Gamer factor appear to be converging, making the latter duplicative. To the extent that the crime-fraud exception does not yet include legal communications facilitating corporate torts, the traditional exception could be expanded. A modified crime-fraud exception would be preferable to the derivative-claim exception because the former could be clearly limited to legal advice concerning prospective misdeeds, ${ }^{191}$ and because it would be a single-factor test which could be predictably applied.

Whether the sought-after communications relate to past or prospective corporate actions is the eighth factor under the good-cause analysis. ${ }^{192}$ Since

183. Gamer, 430 F.2d at 1104 . Saltzburg, supra note 2 , at 834 , wonders why trade secrets are weighed in the balance instead of being treated separately.

184. See, e.g., In re Transocean Tender Offer Litig., 78 F.R.D. 692, 697 (N.D. Ill. 1978); Valente v. Pepsico, Inc., 68 F.R.D. 361,370 (D. Del. 1975).

185. See Fed. R. Civ. P. 26(b)(7).

186. Garner, 430 F.2d at 1104 .

187. The same point is made by Saltzburg, supra note 2 , at 833 . For a discussion of the crimefraud exception, see supra notes $94-99$ and accompanying text.

188. See Garmer, 430 F.2d at 1102, 1104; see also Proposed Fed. R. Evid. 503(d)(1).

189. See In re LTV Sec. Litig., 89 F.R.D. 595, 607-08 (N.D. Tex. 1981). But see Lewis, supra note 133 , at 200.

190. See, e.g., Pfizer, Inc. v. Lord, 456 F.2d 454, 459 (8th Cir. 1972).

191. On limitation to prospective misdeeds, see infra notes $192-96$ and accompanying text.

192. Garner, 430 F.2d at 1104. 
the attorney-client privilege shields legal communications in order to promote observance of the law and the administration of justice, ${ }^{193}$ use of the privilege to facilitate prospective violations of the law constitutes an abuse of the privilege which should not be permitted. ${ }^{194}$ On the other hand, legal communications concerning past events should be privileged because (1) the privilege's purpose is served by corporate self-investigation, and (2) the corporate interest and the plaintiff-shareholders' interests diverge at the time the wrongdoing ends. ${ }^{195}$ Although the past-or-prospective-action element draws a bright line which can be foreseen at the time legal advice is sought, it duplicates the traditional crime-fraud exception by protecting post-event communications from discovery, while withholding protection from legal communications used to further future wrongdoing. ${ }^{196}$

The final element of the Garner analysis is whether the sought-after communication is advice concerning the litigation itself. ${ }^{197}$ This element of the good-cause test borrows from the definition of work product as materials "prepared in anticipation of litigation."'198 Although no court has found good cause to pierce the attorney-client privilege in favor of plaintiffs seeking disclosure of legal advice offered in connection with the litigation itself, 199 the question remains whether a work-product standard should be used to allow discovery of attorney-client communications which would ordinarily be privileged even though they did not occur in connection with the litigation itself. The limitation of work product to materials prepared in anticipation of litigation "serves to formalize a principle upon which nearly all courts have agreed: that protected work product does not include materials prepared in the ordinary course of business, which material is discoverable regardless of whether or not prepared by an attorney." 200 This limitation is necessary in the work-product context because the work-product privilege extends to all documents and tangible items prepared by or for a party, the party's attorney, or their agents. ${ }^{201}$ In contrast, the attorney-client privilege is narrower, shielding only legal communications from discovery. ${ }^{202}$ Thus, although the

193. See Upjohn Co. v. United States, 449 U.S. 383, 389 (1981).

194. One aberrant court found support for a decision not to pierce the attorney-client privilege from the fact that the specified communication pertained to prospective action. Ohio-Sealy Mattress Mfg. Co. v. Kaplan, 90 F.R.D. 21, 31 (N.D. Ill. 1980).

195. In re LTV Sec. Litig., 89 F.R.D. 595, 608 (N.D. Tex. 1981); see also Panter v. Marshall Field \& Co., 80 F.R.D. 718, 723-24 (N.D. Ill. 1978) (allowing discovery of advice contemporaneous with challenged conduct); Cohen v. Uniroyal, Inc., 80 F.R.D. 480, 485 (E.D. Pa. 1978) (allowing discovery of advice antedating challenged conduct).

196. On the distinction between past and prospective action under the traditional crime-fraud exception, see supra notes $92-95$ and accompanying text. Saltzburg, supra note 2 , at 833 , questions "a special distinction between past and prospective actions in shareholder suits, when there is no such distinction in any other suits."

197. Garner, 430 F.2d at 1104 .

198. See Fed. R. CIV. P. 26(b)(3).

199. Cf. Ohio-Sealy Mattress Mfg. Co. v. Kaplan, 90 F.R.D. 21, 31 (N.D. Ill. 1980); Panter v. Marshall Field \& Co., 80 F.R.D. 718,724 (N.D. Ill. 1978).

200. S. Stone \& R. Liebman, Testimonial Privileges § 2.07, at 158 (1983) (citations omitted).

201. See id. § 2.05 .

202. See Upjohn, 449 U.S. at 393, 395. 
concerning-the-litigation-itself standard does not undermine the predictability of the attorney-client privilege (because it is usually possible to know whether advice concerns the litigation at the time it is sought), what is essentially a work-product standard should not be used to narrow further the already narrow attorney-client privilege.

\section{VI}

\section{Conclusion}

The Garner derivative-claim exception unnecessarily undermines the attorney-client privilege by seeking to accomplish a hodgepodge of extrinsic objectives, most of which are already provided for by preexisting exceptions to the privilege or by substantive corporate law. Moreover, the complexity of the Garner test as a whole, as well as the nature of many of its nine elements, makes it difficult to predict whether particular legal advice will remain privileged from shareholder-plaintiffs.

In many areas of the law the cost of leaving issues unresolved is less than the benefit obtained by allowing lower courts to experiment with and develop new approaches to a problem. ${ }^{203}$ Such uncertainty is impermissible in the area of the attorney-client privilege, however, where the goal of full and frank communications depends upon knowing with certainty which discussions will be shielded from discovery. ${ }^{204}$ As the Supreme Court made clear in Upjohn, an uncertain privilege is worth little more than no privilege at all. ${ }^{205}$

Finally, "[i]n light of the vast and complicated array of regulatory legislation confronting the modern corporation, corporations, unlike most individuals, "constantly go to lawyers to find out how to obey the law." "206 The uncertain and weakened privilege engendered by the derivative-claim exception chills the open communication with attorneys that is necessary to maximize voluntary compliance with the law. Thus, the attempt in Garmer to better protect shareholders from corporate wrongdoing may actually be counterproductive, making it more difficult for the corporation to clean its own house and thereby fulfill its duties to its shareholders.

203. See generally B. Cardozo, The Growth of the Law (1924).

204. See Upjohn Co. v. United States, 449 U.S. 383, 392 (1981).

205. See id. at 393.

206. Id. at 392 (quoting Burnham, The Attomey-Client Privilege in the Corporate Arena, 24 Bus. LAw. $901,913(1969))$. 
。 